https://helda.helsinki.fi

\title{
Effects of Acacia seyal and biochar on soil properties and sorghum yield in agroforestry systems in South Sudan
}

\section{Deng, Biar}

\author{
2017-02
}

Deng , B , Tammeorg , P , Luukkanen , O , Helenius , J \& Starr , M 2017 , ' Effects of Acacia seyal and biochar on soil properties and sorghum yield in agroforestry systems in South Sudan ' , Agroforestry Systems , vol. 91 , no. 1 , pp. 137-148 . https://doi.org/10.1007/s10457-016-9914-2

http://hdl.handle.net/10138/214800

https://doi.org/10.1007/s10457-016-9914-2

publishedVersion

Downloaded from Helda, University of Helsinki institutional repository.

This is an electronic reprint of the original article.

This reprint may differ from the original in pagination and typographic detail.

Please cite the original version. 


\title{
Effects of Acacia seyal and biochar on soil properties and sorghum yield in agroforestry systems in South Sudan
}

\author{
Biar Deng • Priit Tammeorg • Olavi Luukkanen • \\ Juha Helenius $\cdot$ Mike Starr
}

Received: 25 June 2015/ Accepted: 22 February 2016/Published online: 27 February 2016

(C) Springer Science+Business Media Dordrecht 2016

\begin{abstract}
We studied the effects of Acacia seyal Del. intercropping and biochar soil amendment on soil physico-chemical properties and sorghum (Sorghum bicolor L.) yields in a two-year field experiment conducted on a silt loam site near Renk in South Sudan. A split-plot design with three replications was used. The main factor was tree-cropping system (dense acacia + sorghum, scattered acacia + sorghum, and sole sorghum) and biochar ( 0 and $10 \mathrm{Mg} \mathrm{ha}^{-1}$ ) was the subplot factor. The two acacia systems had lower soil $\mathrm{pH}, \mathrm{N}$ and higher $\mathrm{C} / \mathrm{N}$ ratios compared to the sole sorghum system. Biochar significantly increased soil C, exchangeable $\mathrm{K}^{+}$contents, field capacity and available water content, but reduced soil exchangeable $\mathrm{Ca}^{2+}$ and effective CEC, and had no effect on soil $\mathrm{pH}$. Acacia intercropping significantly reduced sorghum grain yields while biochar had no significant effect on sorghum yields. The land equivalent ratio (LER) for sorghum yield was 0.3 for both acacia systems in 2011, with or without biochar, but increased in 2012 to 0.6
\end{abstract}

B. Deng $(\bowtie) \cdot$ P. Tammeorg · J. Helenius

Department of Agricultural Sciences, University of Helsinki, (Latokartanonkaari 5), P.O. Box 27, 00014 Helsinki, Finland

e-mail: biar.deng@helsinki.fi

O. Luukkanen · M. Starr

Department of Forest Sciences, University of Helsinki, (Latokartanonkaari 7), P.O. Box 27, 00014 Helsinki, Finland for the scattered acacia system when combined with biochar. The reduction in sorghum yields by the $A$. seyal trees was probably due to a combination of competition for water and nutrients and shading. The lack of a yield response to biochar maybe due to insufficient time or too low a dosage. Further research is needed to test for the effects of tree intercropping and biochar and their interactions on soil properties and crop yields in drylands.

Keywords Acacia seyal - Biochar - Land equivalent ratio (LER) · Savanna · Tree intercropping

\section{Introduction}

Sorghum (Sorghum bicolor (L.) Moench) is the fifth most important cereal globally and an essential food crop in semi-arid areas of sub-Saharan Africa (FAO and ICRISAT 1996; Olembo et al. 2010). Rainfed agriculture provides the bulk of grain production in South Sudan and sorghum is the staple grain for much of the country (IITA 2007; FAO/WFP 2011). However, sorghum yields are declining in the main production areas in the north of the country due to mono-cropping, depletion of soil fertility and erratic climatic conditions (UNEP 2007). Semi-mechanized rainfed agriculture is the major land-use in the study area, but it often lacks appropriate management and is reduced to a sort of shifting cultivation with sorghum 
and/or sesame as the main crops. Traditional rainfed agriculture and irrigated farming are also practised in the area, but crop yields are poor (UNEP 2007). Although some trees are often kept on farms for shade, fruit or gum production, intercropping of annual crops with trees is not widely practiced.

The role and promotion of trees in drylands to restore soil fertility and productivity in Sub-Saharan countries has been the focus of much recent work (Nair and Garrity 2012). The inclusion of trees in tropical agriculture systems is done because they are considered to provide a wide range of facilitative benefits and services, including increased infiltration of rainfall, reduced bare soil evaporation and storm runoff, increased soil moisture, stabilization and protection of soil against wind erosion (due to permanent and deeper rooting), shading, and increased soil organic matter (carbon) contents from pruning and litterfall production (Young 1989; Nair 1993; Gaafar et al. 2006). Increasing soil organic matter (carbon) contents results in increased cation exchange capacity (mineral nutrient retention) and moisture retention of the soil (Raddad et al. 2006; Ong and Leakey 1999). As a result land equivalent ratios (LER; the ratio of intercrop land area to that required to produce the same yield as with the sole crop) are increased, or at least maintained, compared to sole crops (Palm 1995; Hauggaard-Nielsen and Jensen 2005). Although the presence of trees in agroforestry systems is widely assumed to have facilitative effects on crop production, some dryland agroforestry studies have found reduced crop yields and have attributed the reduction to competition for nutrients, water and light (Kessler 1992; Suresh and Rao 1999; Nair and Garrity 2012). Whether the interactions between woody plants and understorey vegetation in savannas is facilitative or competitive has been shown to depend mainly on rainfall (Dohn et al. 2013) but also on the growth form of the woody plants and their capacity to fix $\mathrm{N}$ (Blaser et al. 2013), and the same limitations may be expected for agroforestry in semi-arid regions. Studies of intercropping trees in tropical drylands have focused on Acacia senegal (L.) Willd. and Faidherbia albida Del. Acacia tree-based intercropping has the advantages of producing gum arabic (an economically important product), charcoal and firewood, fodder, and of fixing atmospheric nitrogen into the soil, and both increased (facilitation; LER $>1$ ) and reduced (competition; LER < 1) sorghum crop yields have been reported. For example, in studies carried out in Sudan, Raddad et al. (2006) and Raddad and Luukkanen (2007) did not find any difference in sorghum yield when grown as a sole crop and when intercropped with of 4-year-old A. senegal trees at stocking densities of either 100 or 400 trees per hectare. Gaafar et al. (2006) reported a reduction in sorghum yield with increasing tree density (266-433 trees per hectare), while Fadl (2013) reported increased sorghum yields when intercropped with A. senegal trees. However, little is known about sorghum yields when intercropped with A. seyal. A. seyal is known as a well performing species in semi-arid conditions, it nodulates well and has high rates of nitrogen fixing in certain soils (Abebe 1994, Ganry and Dommergues 1995), making it a good candidate for inclusion in agroforestry systems (Masutha et al. 1997).

Biochar is carbonized biomass produced by pyrolysis under controlled anaerobic conditions and is used to improve soil physico-chemical, particularly increasing nutrient availability, cation exchange capacity and soil moisture and decreasing bulk density (Liang et al. 2006; Major et al. 2010; Peng et al. 2011; Liu et al. 2013; Tammeorg et al. 2014a, c). Depending on biomass source and production conditions, biochar is, however, heterogeneous in composition, texture and properties. Although the use of biochar to improve the soil has recently received considerable attention (Enders et al. 2012), little attention has been paid to its use in drylands (Gwenzi et al. 2015). Significant increases in crop yield when biochar is applied to soil have been widely reported, even in subsistence agriculture practiced in drylands (Lehmann and Rondon 2006; Lehmann and Joseph 2009; Major et al. 2010; Cornelissen et al. 2013). Furthermore, biochar can significantly add to soil carbon sequestration as it is biochemically more stable than the organic matter from which it is made (Cheng et al. 2008) and decomposes more slowly (Woolf et al. 2010; Stavi and Lal 2013). Nevertheless, some studies have reported that amendment of soils with biochar has reduced crop yields (Van Zwieten et al. 2010; Lentz and Ippolito 2012; Nelissen et al. 2014). Negative effects of biochar on crop yields have been attributed to the microbial immobilization of nitrogen (Novak et al. 2010; Nelissen et al. 2014), priming of soil organic matter decomposition (Sohi et al. 2010; Lentz and Ippolito 2012), and contamination of soil with toxic organic compounds and heavy metals (Chan and $\mathrm{Xu}$ 
2009; Jeffery et al. 2015). Biochar has also been found to have no significant effect on soil water availability or soil moisture content in some field studies (Hardie et al. 2014).

In this study the effects of A. seyal and biochar, either alone or in combination, on the physicochemical properties of the soil and yield of sorghum grain were investigated in a field experiment carried out in South Sudan. To our knowledge, this is the first study that has been carried out into the combined effects of tree intercropping and use of biochar on soil properties and agricultural crop yields in semi-arid regions. Given the widely perceived benefits of intercropping with trees and use of biochar on soil properties and crop yields (Steiner et al. 2007; Major et al. 2010), having both trees and biochar might be expected to increase sorghum yields and LER values, perhaps even with synergistic interaction (facilitation $>$ competition and increased soil fertility). However, as has been found in some tree intercropping and biochar studies, it is also possible that sorghum yields and LER values would be reduced in the presence of the A. seyal trees (competition $>$ facilitation) and/or biochar treatment. Our aim was therefore to determine if either A. seyal trees or biochar have (1) significant effects on soil properties, (2) have facilitative or competitive effects on sorghum yield, and (3) whether there was any interaction between the A. seyal tree intercropping and biochar treatments on sorghum yields.

\section{Materials and methods}

Study area

The experiment was conducted on a 0.63 ha abandoned agricultural field $\left(11.97^{\circ} \mathrm{N}, 32.76^{\circ} \mathrm{E}, 380 \mathrm{~m}\right.$ a.s.l.) near to Magara village, $15 \mathrm{~km}$ north of Renk town in South Sudan (Fig. 1). The field has a long history of cropping cotton, sorghum and vegetables when it was part of the Magara Irrigated Agricultural Scheme (cancelled by the central government of Sudan in late 1990s). At the time of this study the field had scattered, naturally regenerated acacia (A. seyal Del., variety seyal (Brenan)) trees growing. A. seyal is the dominant acacia species in the study area (Mohammed and Röhle 2011). The climate is semi-arid with a wet (June-October) and a dry season (November-May). However, rainfall is highly variable in time and space, and dry spells during the wet season are common. Monthly rainfall and temperature during the study period (2011-2012) at the study site and the long-term mean (1998-2010) values at Renk meteorological station are shown in Fig. 2. The long-term mean annual precipitation is $587 \mathrm{~mm}$ and the mean annual temperature is $27.9{ }^{\circ} \mathrm{C}$. The dominant soil type in the area is Vertisol and developed in alluvial sediments. However, the clay at the experiment site is overlain by an approximately $30 \mathrm{~cm}$ thick layer of alluvial silt-loam.

\section{Experimental design and treatments}

The abandoned field was cleared of shrubs and tree species other than Acacia seyal, chisel ploughed to a depth of $30 \mathrm{~cm}$ and then harrowed according to local practice to produce long ridges. A split-plot experiment with two factors (tree-cropping system and biochar treatments) arranged in three blocks was then laid out (Fig. 1). There were 3 replicates of each combination of tree-cropping and biochar treatment. The main plots (tree-cropping system) were $10 \mathrm{~m} \times 10 \mathrm{~m}$ and each was divided into two subplots $(10 \mathrm{~m} \times 5 \mathrm{~m})$ and biochar applied to one of them (randomly selected). After the plots had been laid out the lower branches of the remaining A. seyal trees were pruned and removed from the site. Tree height, diameter at breast height (dbh), and canopy diameter were then measured (Table 1). The uneven distribution of the A. seyal trees allowed two tree density treatments to be defined: dense (plot mean: 400 trees $\mathrm{ha}^{-1}$ ) and scattered (plot mean: 100 trees ha ${ }^{-1}$ ). The tree-cropping treatments (plot factor) were therefore: dense Acacia seyal + sorghum intercropping, scattered Acacia seyal + sorghum intercropping, and sole Sorghum (no trees) (Fig. 3). Biochar, in the form of crushed Acacia seyal charcoal produced in traditional mound kilns (Schenkel et al. 1998), was spread evenly over the surface of the selected subplots and mixed into soil to a depth of approximately $10 \mathrm{~cm}$ using hand hoes. The biochar was applied only once, at the beginning of the experiment (30/7/2011), with each $50 \mathrm{~m}^{2}$ biochar subplot receiving $50 \mathrm{~kg}$ biochar. The biochar treatments (subplot factor) were therefore: no biochar $\left(0 \mathrm{Mg} \mathrm{ha}^{-1}\right)$ and biochar $\left(10 \mathrm{Mg} \mathrm{ha}^{-1}\right)$. The chemical properties of the biochar are presented in Table 2. Liming effect and volatile matter were 


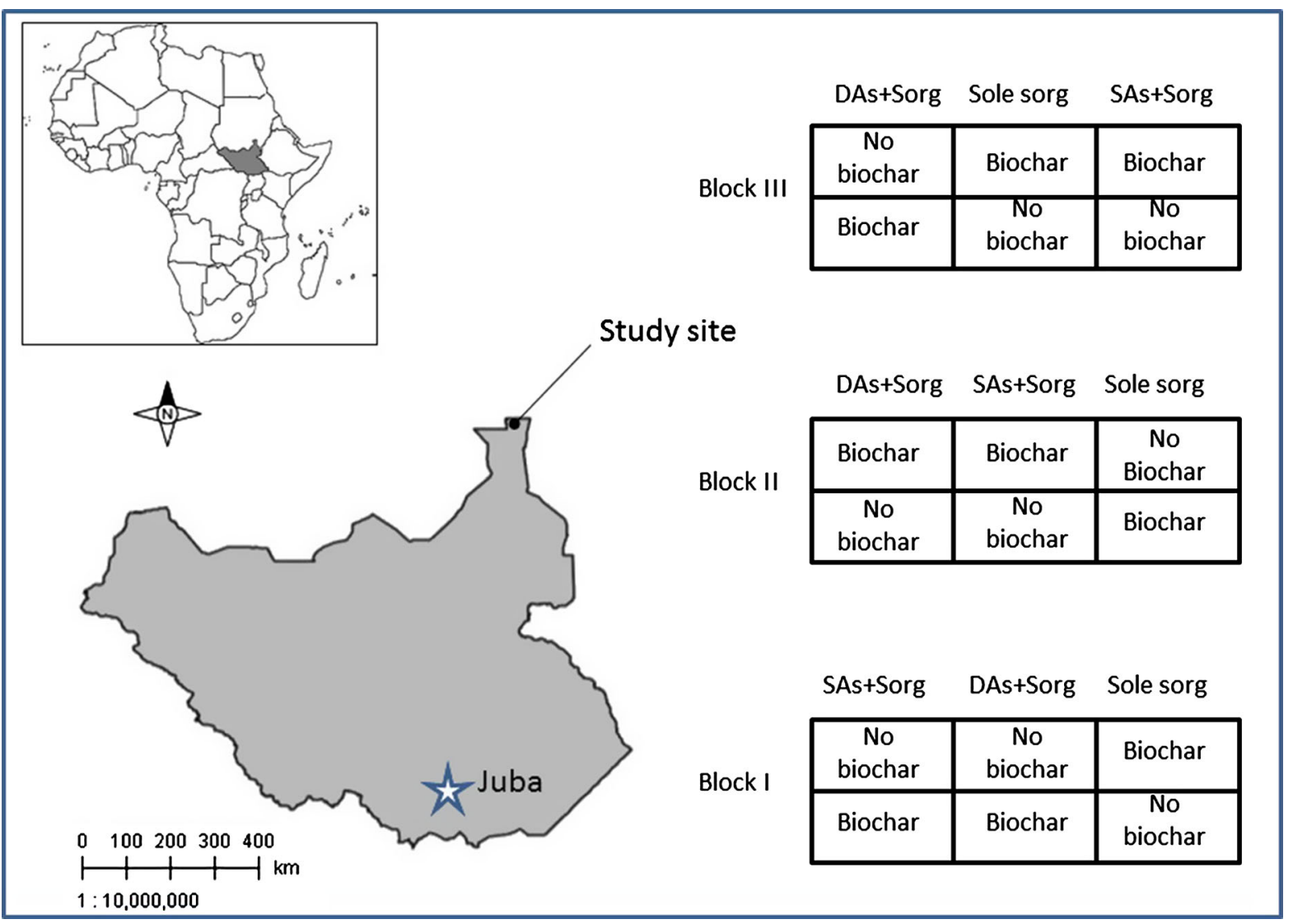

Fig. 1 Map showing location of study site (close to Renk) in South Sudan (inset shows location of South Sudan within Africa) and the design of the split-block experiment. DAs + Sorg = dense Acacia seyal + sorghum, SAs + Sorg = scattered Acacia

determined as described by Tammeorg et al. (2014b), otherwise the properties of the biochar were determined as described for the soils samples $(n=5)$.

Certified seeds of the local variety of sorghum ('Wad Ahmed') were sown on the ridges on 3/8/2011 and $5 / 8 / 2012$. Sowing was made with 5 seeds per hole, which in the third week of germination were thinned to one seedling per hole, resulting in a spacing of $0.7 \mathrm{~m}$ between rows and $0.3 \mathrm{~m}$ between plants. With 14 rows for each subplot, there were thus about 234 plants per subplot (i.e. 46,800 plants $\mathrm{ha}^{-1}$ ). The small size and density of the trees (Table 1) meant that the density of sorghum plants was not significantly affected by the tree-cropping treatments. No chemical fertilizer or insecticides were applied to the experiment, but 2,4Dichlorophenoxyacetic acid (commercially known as 2,4-D) herbicide was applied once (29/8/2011) to control broadleaved weeds. Gramineae weeds were seyal + sorghum, and Sole sorg $=$ sole sorghum cropping systems; No biochar and Biochar refer to the biochar treatments, 0 and $10 \mathrm{Mg} \mathrm{ha}^{-1}$

manually removed twice during the growing season in both years.

Sampling and analysis

Three replicate soil samples from the $0-30 \mathrm{~cm}$ layer of each subplot were taken at the end of the second cropping season (20/11/2012) using a soil auger. After drying the soil samples at $60{ }^{\circ} \mathrm{C}$ for $72 \mathrm{~h}$, they were sieved and the weight of $>2$ and $<2 \mathrm{~mm}$ fractions recorded. The $<2 \mathrm{~mm}$ fraction was saved for analyses and the following properties determined: $\mathrm{pH}$, total and plant available contents of $\mathrm{Ca}, \mathrm{Mg}$ and $\mathrm{K}$, cation exchange capacity (CEC) and base saturation, ash, total carbon $(\mathrm{C})$ and nitrogen $(\mathrm{N})$ contents, and particle size distribution.

Soil acidity $(\mathrm{pH})$ was measured in a suspension (1:5) of soil and distilled/deionised water using a 
Fig. 2 Monthly mean air temperature $\left({ }^{\circ} \mathrm{C}\right)$ and rainfall $(\mathrm{mm})$ in 2011 and 2012 recorded at the research site and the longterm (1998-2010) average values recorded at Renk meteorological station

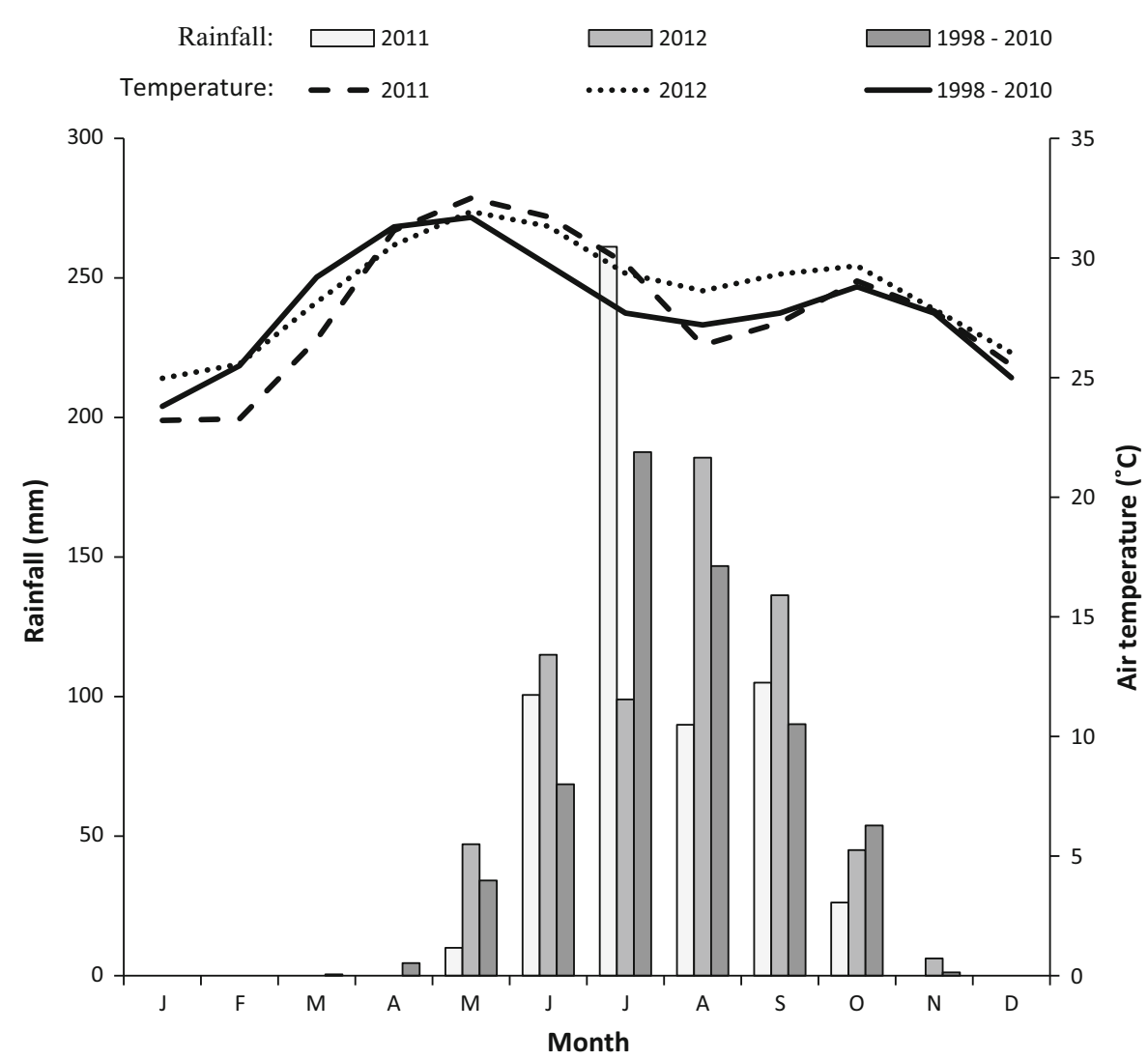

Table 1 Mean characteristics of the Acacia seyal trees in the field experiment by tree-cropping system and biochar treatment

\begin{tabular}{llllll}
\hline Tree-cropping system & Biochar treatment & Stems $\left(\mathrm{ha}^{-1}\right)$ & DBH $(\mathrm{cm})$ & Height $(\mathrm{m})$ & Canopy cover $(\%)$ \\
\hline Dense Acacia & No biochar & 467 & 4.3 & 4.2 & 18 \\
& Biochar & 333 & 3.8 & 3.3 & 9 \\
Scattered Acacia & No biochar & 67 & 5.2 & 2.9 & 14 \\
& Biochar & 133 & 6.6 & 4.3 & 38 \\
\hline
\end{tabular}

standard $\mathrm{pH}$ meter. Ash content was determined by dry combustion in a muffle furnace at a temperature of $500{ }^{\circ} \mathrm{C}$ for $2 \mathrm{~h}$. Plant available contents of $\mathrm{Ca}, \mathrm{Mg}$ and $\mathrm{K}$ were determined from a $0.1 \mathrm{M} \mathrm{BaCl}_{2}$ extraction by ICP-OES (Thermo Scientific iCAP 6000 Series, Thermo Scientific, Waltham, USA). CEC was calculated as the sum of $0.1 \mathrm{M} \mathrm{BaCl}_{2}$ extractable $\mathrm{Ca}, \mathrm{Mg}, \mathrm{K}$ and exchangeable acidity; the latter being determined by titration of the $0.1 \mathrm{M} \mathrm{BaCl}_{2}$ extraction to a $\mathrm{pH}$ endpoint of 8.2 using $0.01 \mathrm{~m} \mathrm{NaOH}$. Total $\mathrm{C}$ and $\mathrm{N}$ contents were determined using a VarioMax elemental analyzer (Elementar Analysensysteme GmbH, Hanau, Germany) and total elemental composition determined from a concentrated $\mathrm{HNO}_{3}$ acid microwaved digestion using ICP-OES. Particle size distribution of the $<2 \mathrm{~mm}$ fraction was determined using a laser diffraction device (Coulter LS230, Coulter Corporation, Miami, USA) and the contents of clay, silt and sand fractions calculated. The soil hydraulic properties field capacity (FC, vol/vol), permanent wilting point (PWP, vol/vol) and available water capacity (AWC, $\mathrm{vol} / \mathrm{vol}$ ) were calculated using the measured sand, clay and organic matter contents and the pedotransfer functions developed by Saxton and Rawls (2006). Before applying the pedotransfer functions, measured zero sand and clay contents were substituted with a value of $0.1 \%$ and organic matter contents were taken to be double the measured $\mathrm{C} \%$ contents. 

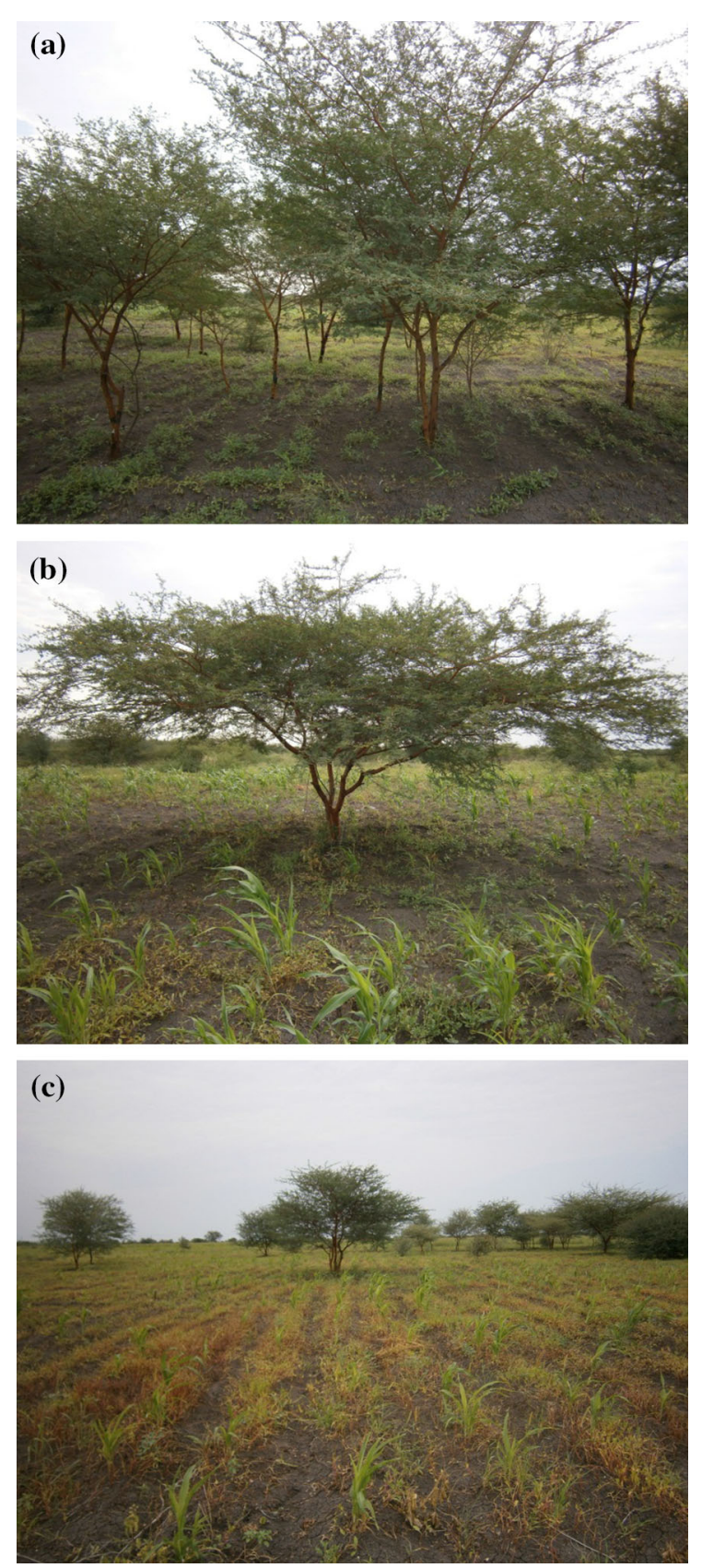

Fig. 3 Photographs of the a Dense Acacia + Sorghum intercropping, b Scattered Acacia + Sorghum intercropping, and c Sole Sorghum intercropping systems at the Magara study site. (Photos taken by Biar Deng 2011)

Sorghum plant height, stem diameter and panicle length of ten randomly selected plants from each subplot were recorded at the harvest time, 6/11/2011 and $10 / 11 / 2012$. Height was measured from the base of the plant to the tip of the tallest leaf with a scaled
Table 2 Composition and properties of the biochar used in the field experiment

\begin{tabular}{lcl}
\hline Property & Value & Unit \\
\hline $\mathrm{pH}$ (in water) & 7.3 & - \\
Liming effect & 0.5 & $\mathrm{~mol} \mathrm{~kg}^{-1}$ \\
Effective CEC & 20.6 & $\mathrm{cmol}_{(+)} \mathrm{kg}^{-1}$ \\
Ash & 24.0 & $\%$ \\
Volatile matter & 32.8 & $\%$ \\
$\mathrm{C}$ & 69.4 & $\%$ \\
$\mathrm{~N}$ & 0.08 & $\%$ \\
$\mathrm{C} / \mathrm{N}$ & 86.8 & - \\
$\mathrm{Ca}$ & 22.9 & $\mathrm{~g} \mathrm{~kg}^{-1}$ \\
$\mathrm{Mg}$ & 13.5 & $\mathrm{~g} \mathrm{~kg}^{-1}$ \\
$\mathrm{~K}$ & 95.8 & $\mathrm{~g} \mathrm{~kg}^{-1}$ \\
$\mathrm{P}$ & 16.8 & $\mathrm{~g} \mathrm{~kg}^{-1}$ \\
\hline
\end{tabular}

ruler. Plant stem diameter was measured using Vernier calipers and panicle length measured using a ruler. Sorghum dry weight (stems and leaves) was determined by sun drying to constant weight. Sorghum yield $\left(\mathrm{Mg} \mathrm{ha}^{-1}\right)$ was calculated from the combined weight of the seed grain collected from another ten sorghum plants sampled from each subplot and the number of plants per hectare. Land Equivalent Ratios (LER) was calculated as the ratio of the intercrop land area to that required to produce the same yield as in the sole crop (Hauggaard-Nielsen and Jensen 2005; Fadl and El sheikh 2010). A LER value of $<1.0$ indicates that the intercropping is disadvantageous for crop yield (competition by trees) while a value $>1.0$ indicates tree intercropping is advantageous for crop yields (facilitation dominates over competitive interference).

\section{Statistical analysis}

The characteristics of the trees, soil and sorghum by cropping system and biochar treatment are described by the mean and standard deviation. The effects of tree-cropping system, biochar treatment, year (in the case of sorghum yield) and their interactions on soil properties and sorghum yield were tested for using univariate analysis of variance (ANOVA). Tree-cropping system, biochar treatment, and year (2011 and 2012) were considered as fixed effect factors. Homogeneity of variances were tested for using Levene's test, post hoc tests for the effect of cropping system 
were conducted using Tukey's HSD test, and the effect of biochar treatment and year was tested for using the $t$ test. SPSS software version 22.00 (SPSS Corp., Chicago, USA) was used.

\section{Results}

Effects of trees and biochar on soil properties

The intercropping systems with acacia trees had lower soil $\mathrm{pH}, \mathrm{N}$, total and exchangeable $\mathrm{Ca}^{2+}$ contents, and higher $\mathrm{C} / \mathrm{N}$ ratios compared to the sole sorghum system, but otherwise there no other significant $(p>0.05)$ differences in soil properties between cropping systems (Table 3; Fig. 4a).

The biochar application significantly increased soil $\mathrm{C}$ and exchangeable $\mathrm{K}^{+}$contents as well as the soil hydraulic properties of field capacity and plant available water capacity, and significantly decreased contents of exchangeable $\mathrm{Ca}^{2+}$ and CEC (Table 3). However, the biochar treatment had no significant effect on soil $\mathrm{pH}$ (Table 3) or on total mineral nutrient and sulphur contents (Fig. 4b).

Effects of trees and biochar on sorghum yield

As sorghum above-ground biomass, stem height and stem diameter were all highly correlated to yield (Spearman correlations from 0.77 to $0.86, p<0.01$, $n=36)$, only the results for grain yield $\left(\mathrm{Mg} \mathrm{ha}^{-1}\right)$ and LER are discussed further. There was no significant interaction between cropping system and biochar treatment so that the effects of these two main factors could be evaluated separately. The tree intercropping systems had a highly significant effect on sorghum grain yield, with yields being greatly reduced by the presence of trees $(F=837, p<0.001$, Fig. 5a). The difference between the cropping systems was more pronounced in the first year when sorghum yields when grown alone were about $400 \%$ of the yields in the dense Acacia + sorghum cropping system, compared to about $300 \%$ better in the second year (interaction between cropping system and year, $p<0.001$, Fig. 5a). In the first year (2011) sorghum grain yields were only about half of what was obtained in the second year (2012) and the difference between years was significantly different $(p<0.001)$. In contrast to the cropping system, the biochar treatment did not have a significant main effect $(p=0.593)$ or interaction with cropping system $(p=0.144)$ or year $(p=0.562)$ on sorghum grain yield (Fig. 5b).

Compared to the sole sorghum system, LER values were 0.3 for the dense $A$. seyal intercropped treatment in both years and with both biochar treatments. For the scattered A. seyal intercropping system the LER value was 0.3 in 2011 for both biochar treatments, but increased to 0.6 in 2012.

\section{Discussion}

The presence of the A. seyal trees had a significant effect on soil $\mathrm{pH}, \mathrm{N}$ and $\mathrm{C} / \mathrm{N}$ ratio but not on soil $\mathrm{C}$,

Table 3 Soil properties (mean values) of the 0-30 cm layer by tree-cropping system and biochar treatment

\begin{tabular}{|c|c|c|c|c|c|c|c|c|c|c|}
\hline Treatment & $\begin{array}{l}\mathrm{pH} \\
\text { (water) }\end{array}$ & $\begin{array}{l}\mathrm{C} \\
(\%)\end{array}$ & $\begin{array}{l}\mathrm{N} \\
(\%)\end{array}$ & $\mathrm{C} / \mathrm{N}$ & $\begin{array}{l}\mathrm{K}^{+} \\
\mathrm{cmol}_{(+)} \\
\mathrm{kg}^{-1}\end{array}$ & $\begin{array}{l}\mathrm{Ca}^{2+} \\
\mathrm{cmol}_{(+)} \\
\mathrm{kg}^{-1}\end{array}$ & $\begin{array}{l}\mathrm{Mg}^{2+} \\
\mathrm{cmol}_{(+)} \\
\mathrm{kg}^{-1}\end{array}$ & $\begin{array}{l}\mathrm{CEC} \\
\mathrm{cmol}_{(+)} \\
\mathrm{kg}^{-1}\end{array}$ & $\begin{array}{l}\mathrm{FC} * \\
\mathrm{v} / \mathrm{v} \%\end{array}$ & $\begin{array}{l}\text { AWC* } \\
\text { v/v\% }\end{array}$ \\
\hline \multicolumn{11}{|l|}{ Tree-cropping system } \\
\hline Dense Acacia + Sorghum & $7.98^{\mathrm{ab}}$ & $0.81^{\mathrm{a}}$ & $0.05^{\mathrm{a}}$ & $14.2^{\mathrm{a}}$ & $0.50^{\mathrm{a}}$ & $28.7^{\mathrm{a}}$ & $10.1^{\mathrm{a}}$ & $39.3^{\mathrm{a}}$ & $26^{\mathrm{a}}$ & $23^{\mathrm{a}}$ \\
\hline Scattered Acacia + Sorghum & $7.93^{\mathrm{a}}$ & $0.92^{\mathrm{a}}$ & $0.22^{\mathrm{a}}$ & $5.9^{\mathrm{b}}$ & $0.61^{\mathrm{a}}$ & $30.8^{\mathrm{b}}$ & $10.5^{\mathrm{a}}$ & $42.0^{\mathrm{a}}$ & $25^{\mathrm{a}}$ & $22^{\mathrm{a}}$ \\
\hline Sole Sorghum & $8.06^{\mathrm{b}}$ & $1.02^{\mathrm{a}}$ & $0.95^{\mathrm{b}}$ & $1.3^{\mathrm{c}}$ & $0.52^{\mathrm{a}}$ & $28.9^{\mathrm{a}}$ & $10.8^{\mathrm{a}}$ & $40.3^{\mathrm{a}}$ & $25^{\mathrm{a}}$ & $22^{a}$ \\
\hline \multicolumn{11}{|l|}{ Biochar } \\
\hline No biochar & $8.00^{\mathrm{A}}$ & $0.58^{\mathrm{A}}$ & $0.27^{\mathrm{A}}$ & $6.9^{\mathrm{A}}$ & $0.47^{\mathrm{A}}$ & $30.5^{\mathrm{A}}$ & $10.7^{\mathrm{A}}$ & $41.7^{\mathrm{A}}$ & $21^{\mathrm{A}}$ & $20^{\mathrm{A}}$ \\
\hline Biochar & $7.98^{\mathrm{A}}$ & $1.25^{\mathrm{B}}$ & $0.54^{\mathrm{A}}$ & $7.3^{\mathrm{A}}$ & $0.62^{\mathrm{B}}$ & $28.4^{\mathrm{B}}$ & $10.2^{\mathrm{A}}$ & $39.3^{\mathrm{B}}$ & $29^{\mathrm{B}}$ & $26^{\mathrm{B}}$ \\
\hline
\end{tabular}

Differences between tree-cropping systems (ANOVA and Tukey HSD multiple comparisons) and biochar treatments $(t$ test; variances assumed not equal) are included. Values followed by the same letter indicate no significant difference $(\alpha=0.05)$

* Field capacity (FC) and available water capacity (AWC) are estimates calculated using the pedotransfer functions developed by Saxton and Rawls (2006) 

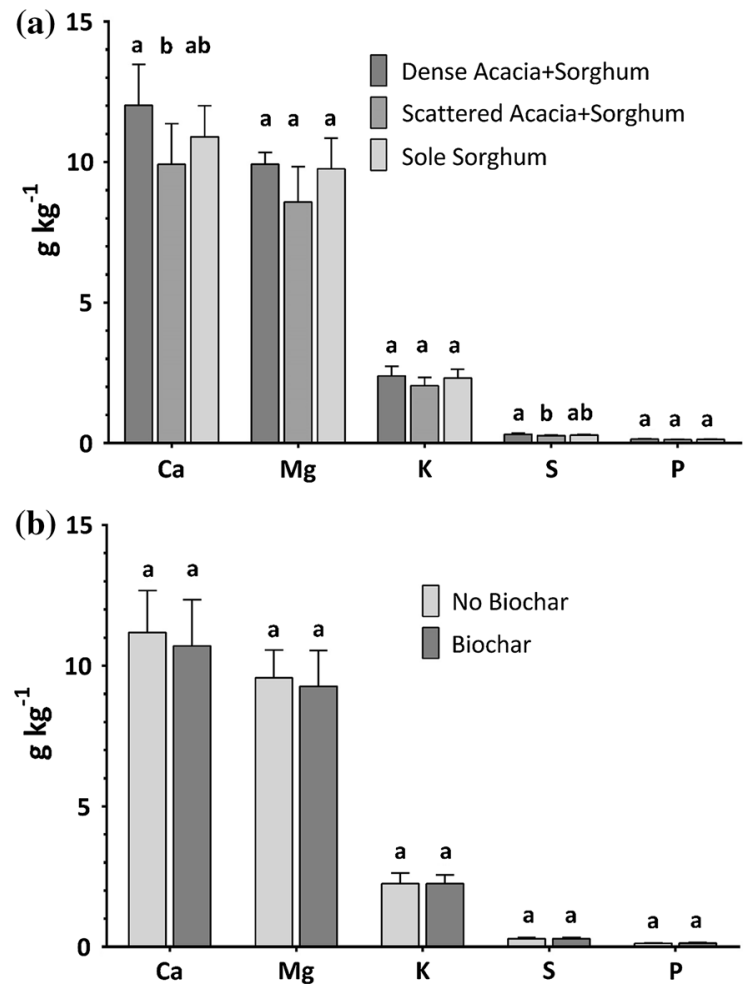

Fig. 4 Total elemental concentrations $\left(\mathrm{g} \mathrm{kg}^{-1}\right)$ of mineral nutrients $(\mathrm{Ca}, \mathrm{Mg}, \mathrm{K}$ and $\mathrm{P})$ and sulphur $(\mathrm{S})$ in the soil $(0-30 \mathrm{~cm})$ by a tree-cropping system and by $\mathbf{b}$ biochar treatment at the Magara study site. Columns are means and error bars are standard deviations. For each element, the same lower case letters above each bar indicates a non-significant difference while different letters indicates a significant difference $(\alpha=0.05)$ (ANOVA, post hoc Tukey HSB test)

total and exchangeable mineral nutrient contents, CEC or soil hydraulic properties (Fig. 4 and Table 3). Because litterfall from the acacia trees would have increased input of organic matter to the soil and because of the relatively low rate of decomposition of acacia litterfall (Bernhard-Reversat 2002), we had expected higher soil $\mathrm{C}$ contents and related increases in nutrient contents, CEC and water retention capacity under the two tree-cropping treatments compared to the pure sorghum treatment as has been found in other dryland agroforestry studies concerning the effects of trees on soil properties. For example, El-Tahir et al. (2004) reported increased $\mathrm{P}, \mathrm{N}$ and $\mathrm{C}$ contents under $A$. seyal growing on sandy soils in North Kordofan compared to bare soil and under A. senegal and Acacia tortilis, and Belsky et al. (1989), Buresh and Tian (1998) and Abdallah and Chaieb (2012) all reported higher contents of organic matter, N, P, K and $\mathrm{Ca}$
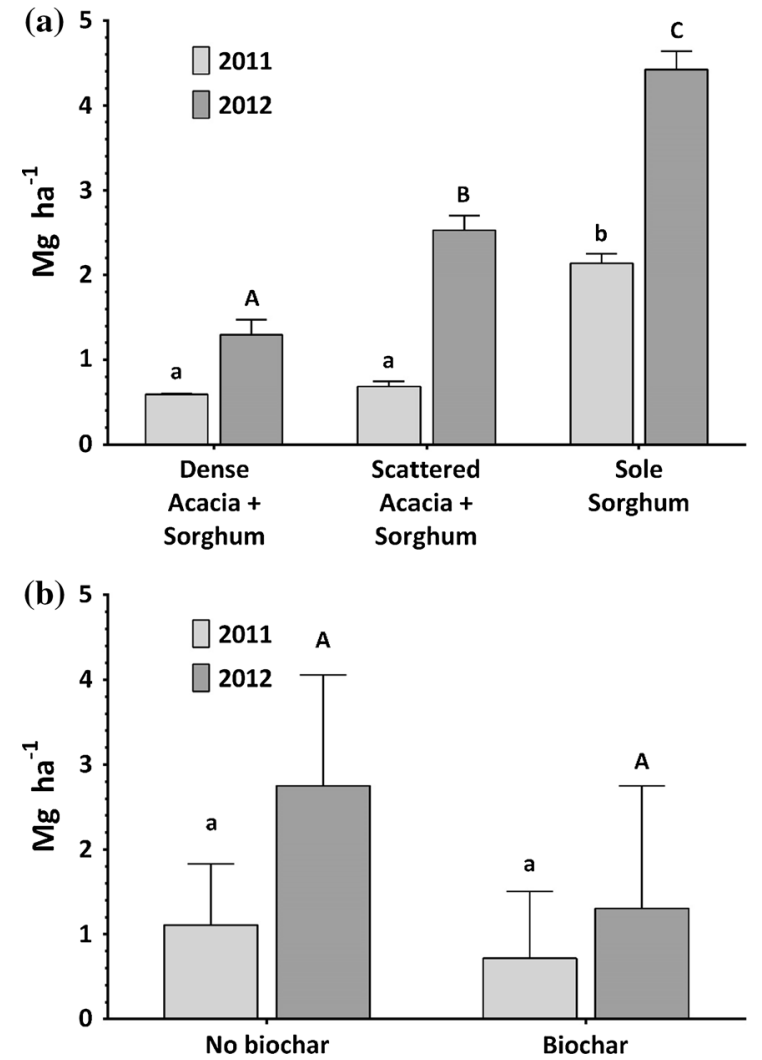

Fig. 5 Mean (error bars are standard deviations) sorghum grain yield $\left(\mathrm{Mg} \mathrm{ha}^{-1}\right)$ by a Tree-cropping system and $\mathbf{b}$ Biochar treatment in 2011 and 2012. Non-significant differences between tree-cropping system and between biochar treatment are indicated by the same letter, lower case letters for 2011 and upper case letters for $2012(\alpha=0.05$; ANOVA post hoc Tukey HSB test)

under dryland (savanna) trees canopies compared to open areas.

Although soil $\mathrm{N}$ contents in our study did significantly differ among the cropping treatments, they were the lowest under the two tree intercropping treatments compared to the sole sorghum treatment. We had expected soil $\mathrm{N}$ contents to be higher under the tree intercropping treatments because of $\mathrm{N}$-fixation by the acacia trees (Buresh and Tian 1998). Evidently, any addition of $\mathrm{N}$ to the soil resulting from $\mathrm{N}$-fixation by the acacia trees had been more than offset by the mineralization of organic $\mathrm{N}$ and subsequent loss of $\mathrm{N}$ through uptake by the trees or leaching, leaving behind soil organic matter depleted in $\mathrm{N}$. The observed differences in soil $\mathrm{C} / \mathrm{N}$ ratios among the cropping treatments was therefore due to differences in the $\mathrm{N}$ content of the soil organic matter rather than to 
differences in $\mathrm{C}$ content. The lower soil $\mathrm{pH}$ in the acacia intercropping treatments compared to sole sorghum, which was significant in the case of the scattered acacia treatment, is probably due to the known high phenolic content of acacia, especially $A$. seyal, litterfall (Bernhard-Reversat 1987).

Several studies have shown that biochar increases nutrient retention in soils, especially in highly weathered, acidic and sandy soils with low initial C content (Cornelissen et al. 2013; Liu et al. 2013). There is also evidence that biochar can also improve the physicochemical properties of clayey soils (De Melo Carvalho et al. 2013, Ouyang et al. 2013, Tammeorg et al. 2014a). In our study the biochar treatment had a significant effect on the $\mathrm{C}$ content, exchangeable chemistry and hydraulic properties of the soil, but not on total nutrient contents (Table 3). As expected, soil $\mathrm{C}$ contents, field capacity and available water capacity increased as the result of the biochar application. However, CEC, contrary to what had been expected, decreased as result of the biochar treatment. While the contents of exchangeable $\mathrm{K}^{+}$ increased, these were offset by reductions in the contents of exchangeable $\mathrm{Ca}^{2+}$ and $\mathrm{Mg}^{2+}$ resulting in the reduced CEC values. Increased soil $\mathrm{K}$ contents after biochar treatment have been attributed to the direct fertilization effect of woody biochar, which is rich in K (Glaser et al. 2002). Several studies from the tropics (Liang et al. 2006; Major et al. 2010; Peng et al. 2011) have shown that soil $\mathrm{Ca}$ contents are also increased by biochar. A possible explanation for the reduced soil contents of $\mathrm{Ca}^{2+}$ and $\mathrm{Mg}^{2+}$ found in our study could be through exchange with $\mathrm{K}^{+}$and leaching (Tammeorg et al. 2014c). Besides the reduction in exchangeable $\mathrm{Ca}^{2+}$ and $\mathrm{Mg}^{2+}$ contents, the reduced $\mathrm{CEC}$ values could be due to a dilution effect. As the CEC of the biochar (Table 2) was half that of the untreated soil (Table 3), the addition of biochar may have diluted the CEC of the soil. Biochar had no significant effect on soil $\mathrm{pH}$, which is not surprising considering its low liming effect and that the soil $\mathrm{pH}$ in our study was slightly more alkaline than that of the biochar (Tables 2, 3). Although soil $\mathrm{N}$ contents were higher in the biochar treated subplots compared to the no biochar subplots, the difference was not significant (Table 3). This contrasts with other studies that found biochar increases soil $\mathrm{N}$ contents when intercropping with $\mathrm{N}$-fixing plants (Rondon et al. 2007; Van Zwieten et al. 2015).
The A. seyal trees clearly had a negative (i.e. competitive) effect on sorghum yield (LER $<1.0$ ). There are no studies dealing with $A$. seyal intercropping, however, our results are in agreement with results reported from $A$. senegal-sorghum intercropping experiments. Gaafar et al. (2006) reported a significant decrease in sorghum and karkadeh (Hibiscus sabdariffa) yields when intercropped with 6-year-old $A$. senegal trees (266 and 433 trees $\mathrm{ha}^{-1}$ ) in North Kordofan, Sudan. They attributed this decrease in yields to competition between the tree and crop roots for water. Fadl and El Sheikh (2010), also working in North Kordfan, reported reduced yields of groundnut (Arachis hypogaea), karkadeh and sesame (Sesamum indicum) when intercropped with 15-year-old A. senegal trees (375 trees $\mathrm{ha}^{-1}$ ). However, these results contrast with those reported by Raddad et al. (2006), who found no significant effect on sorghum yields when intercropped with A. senegal, and by Fadl (2013), who reported significant increases (i.e. facilitation) in the yields of sorghum, karkadeh and sesame yield when intercropped with 11-year-old A. senegal trees. This variation in crop yields when intercropped with trees, would suggest that the effect of trees on crop yields depends on the age, size and density of trees and on the year to year variation in environmental conditions, particularly precipitation (Danso et al.1992).

Acacia, having taproots and small lateral roots, was expected to extract water from deeper soil layers and so not be in competition with the shallow rooting sorghum (Adams 1967; Gaafar et al. 2006). However, the acacia trees in our study were small (young) and therefore their roots may not yet have penetrated deeper into soil and thereby have been in competition with the sorghum roots for water and nutrients. In addition, the roots of the acacia trees may not have been able to penetrate the underlying clay at our site, accentuating the competition between the acacia tree and sorghum roots for water and nutrients. Furthermore, A. seyal has a dense canopy cover (cf. A. senegal) and sorghum does not grow well in shade (Wilson et al. 1998; Gnanglè et al. 2013). The reduction in intercropped sorghum yields was therefore probably also a result of shading (Belsky 1994). The smaller size of the sorghum plants under the acacia canopy is clearly seen in the photographs of the intercropping systems (Fig. 3). Even though sorghum is drought-hardy the lower sorghum yield in 2011 compared to 2012 yields is probably because 2011 was 
drier than 2012 (August-November rainfall 221 vs. $373 \mathrm{~mm}$ ).

The effects of biochar on crop yield and growth are known to differ greatly due to variability in biochar type, application rates and time since application, soil type and climate (Blackwell et al. 2009; Major et al. 2010). However, most studies report neutral to positive (facultative) effects of biochar on crop yields (Biederman and Harpole 2013; Liu et al. 2013).We had therefore expected the biochar treatment in our experiment, by improving soil moisture and retention capacities, would increase sorghum yields, especially when combined with the expected facilitative effects of the acacia trees. However, we found that biochar had no significant effect on sorghum yields in spite of the improvements in soil properties we found, that the presence of the A. seyal trees significantly reduced sorghum yields, and that there was no significant interaction between biochar and trees on sorghum yields. Cornelissen et al. (2013) observed that the effects of biochar on maize yield in Zambia depended on soil type. While they found no detectable increase in maize grown in acidic and neutral clay-loams and siltyclay sites, significantly higher yields were recorded from a coarse acidic sandy site even when having a lower biochar dose. De Melo Carvalho et al. (2013) also did not observe any effect of biochar on rice grain yields grown on a Brazilian savanna clay soil. The effects of biochar on crop yields have been shown to become only significant in the long-term and to have a cumulative effect on crop yields, possibly via the slow release of nutrients and changes in soil microbiological community (Steiner et al. 2007; Kimetu et al. 2008; Major et al. 2010). For immediate effects on crop yields, higher doses of biochar than the $10 \mathrm{Mg} \mathrm{ha}^{-1}$ used in our experiment may be needed (Major et al. 2010; Tammeorg et al. 2014b). Thus the failure of biochar to increase sorghum yields in our study may be because of the soil type, the short duration of the study, and the relatively low dosage of biochar used. However, very little is known about the effects of biochar in drylands, especially in sub-Saharan Africa, and more research is needed (Gwenzi et al. 2015).

\section{Conclusions}

The present study showed that intercropping sorghum with $A$. seyal rather than having a facultative effect and increasing sorghum yields, as expected, had the opposite effect and significantly reduced sorghum yields. Other than increasing $\mathrm{C} / \mathrm{N}$ ratios, the presence of the acacia trees had little effect on soil properties. We concluded that the reduction in sorghum yields was due to a combination of competition for water and nutrients and shading by the A. seyal. However, further research is needed to see how representative this competition is of A. seyal intercropping. The application of biochar had no significant effect on sorghum yields even though a number of soil properties were changed (increased soil $\mathrm{C}$ and exchangeable $\mathrm{K}^{+}$contents and water retention) indicating improved soil fertility. Furthermore, there was no interaction between the presence of trees and biochar treatment on sorghum yields. It may be that more time is needed before the benefits of biochar on soil properties are transferred to increases in crop yield. Clearly, further research is needed to test for the effects of tree intercropping and biochar and their interactions on soil properties and crop yields in drylands, especially in the long-term.

Acknowledgments We acknowledge funding support from the Landscape Management Planning and Training for the Environment in Southern Sudan (LAMPTESS) project, and Department of Agricultural Sciences, Faculty of Agricultural and Forestry, University of Helsinki. We also are indebted to the staff of faculties of Agricultural and Forestry, University of Upper Nile, South Sudan for their help and facilitation in the field work. The technical assistance in the laboratory during the chemical analysis of the samples at the University of Helsinki, Finland by Prof. Markku Yli-Halla and laboratory technician Marjut Wallner are appreciated.

\section{References}

Abdallah F, Chaieb M (2012) The influence of trees on nutrients, water, light availability and understorey vegetation in an arid environment. Appl Veg Sci 15:501-512. doi:10.1111/ j.1654-109X.2012.01201.x

Abebe T (1994) Growth performance of some multipurpose trees and shrubs in the semi-arid areas of Southern Ethiopia. Agrofor Syst 26:237-248

Adams ME (1967) A Study of the Ecology of Acacia mellifera, Acacia and Balanites aegyptiaca in relation to land-clearing. J Appl Ecol 4:221-237

Belsky AJ (1994) Influences of trees on savanna productivity: tests of shade, nutrients, and tree-grass competition. Ecology 75:922-932

Belsky AJ, Amundson RG, Duxbury JM, Riha SJ, Ali AR, Mwonga SM (1989) The effects of trees on their physical, chemical and biological environments in a semi-arid savanna in Kenya. J Appl Ecol 26:1005-1024 
Bernhard-Reversat F (1987) Litter incorporation to soil organic matter in natural and planted tree stands in Sengal. Pedobiologia 30:401-417

Bernhard-Reversat F, Loumeto JJ (2002) The litter system in African forest-tree plantations. In: Vikram Reddy M (ed) Management of tropical plantation-forests and their soil litter system: litter, biota and soil-nutrient dynamics. Science Publishers Inc, Enfield, NH, USA, pp 11-39

Biederman LA, Harpole WS (2013) Biochar and its effects on plant productivity and nutrient cycling: a meta-analysis. Glob Chang Biol Bioenergy 5:202-214. doi:10.1111/gcbb. 12037

Blackwell P, Riethmuller G, Collins M (2009) Biochar application to soil. In: Lehmann J, Joseph S (eds) Biochar for environmental management: science and technology. Earthscan, London, pp 207-226

Blaser WJ, Sitters J, Hart SP, Edwards PJ, Olde Venterink H (2013) Facilitative or competitive effects of woody plants on understorey vegetation depend on $\mathrm{N}$-fixation, canopy shape and rainfall. J Ecol 101:1598-1603. doi:10.1111/ 1365-2745.12142

Buresh RJ, Tian G (1998) Soil improvement by trees in subSaharan Africa. Agrofor Syst 38:51-76

Chan KY, Xu Z (2009) Nutrient properties and their enhancement. In: Lehmann J, Joseph S (eds) Biochar for environmental management: science and technology, 1st edn. Earthscan, London, pp 67-84

Cheng C-H, Lehmann J, Thies JE, Burton SD (2008) Stability of black carbon in soils across a climatic gradient. J Geophys Res 113:G02027. doi:10.1029/2007JG000642

Cornelissen G, Martinsen V, Shitumbanuma V, Alling V, Breedveld G, Rutherford D, Sparrevik M, Hale S, Obia A, Mulder J (2013) Biochar effect on maize yield and soil characteristics in five conservation farming sites in Zambia. Agronomy 3:256-274. doi:10.3390/agronomy3020256

Danso SKA, Bowen GD, Sanginga N (1992) Biological nitrogen-fixation in trees in agroecosystems. Plant Soil 141: 177-196

De Melo Carvalho MT, Madari BE, Bastiaans L, van Oort PAJ, Heinemann AB, da Silva MAS, de Holanda Nunes Maia A, de Meinke H (2013) Biochar improves fertility of a clay soil in the Brazilian Savannah: short term effects and impact on rice yield. J Agric Rural Dev Trop Subtrop 114:101-107

Dohn J, Dembélé F, Karembé M, Moustakas A, Amévor KA, Hanan NP (2013) Tree effects on grass growth in savannas: competition, facilitation and the stress-gradient hypothesis. J Ecol 101:202-209. doi:10.1111/1365-2745.12010

El-Tahir BA, El-Hag FM, Madibo GM, El-Wakeel AS (2004) Influence of Acacia Senegal, Acacia seyal and Acacia tortilis on some properties of sandy soil in North Kordofan State, Sudan. Univ Khartoum J Agric Sci 12(1):127-141

Enders A, Hanley K, Whitman T, Joseph S, Lehmann J (2012) Characterization of biochars to evaluate recalcitrance and agronomic performance. Bioresour Technol 114:644-653

Fadl KM (2013) Influence of Acacia Senegal agroforestry system on growth and yield of sorghum, sesame, roselle and gum in north Kordofan State, Sudan. J For Res 24: 173-177. doi:10.1007/s11676-012-0319

Fadl KM, El sheikh SE (2010) Effect of Acacia senegal on growth and yield of groundnut, sesame and roselle in an agroforestry system in North Kordofan state, Sudan. Agrofor Syst 78:243-252. doi:10.1007/s10457-009-92 43-9

FAO and ICRISAT (1996) The World Sorghum economies; facts, trends and outlook. FAO, Rome and ICRISAT, Andhra Pradesh

FAO and WFP (2011) Crop and food security assessment mission to southern Sudan. Special Report, pp. 52. Accessed on 10 Jun 2012

Gaafar AM, Salih AA, Luukkanen O, El Fadl MA, Kaarakka V (2006) Improving the traditional Acacia senegal-crop system in Sudan: the effect of tree density on water use, gum production and crop yields. Agrofor Syst 66:1-11

Ganry F, Dommergues YR (1995) Arbres fixateurs d'azote: champ ouvert pour la recherche. Agric Dev 7:38-55

Glaser B, Lehmann J, Zech W (2002) Ameliorating physical and chemical properties of highly weathered soils in the tropics with charcoal-a review. Biol Fertil Soils 35:219-230. doi:10.1007/s00374-002-0466-4

Gnanglè CP, Gbemavo C, Aihou K, Kakai RG, Sokpon N (2013) Productivity of cotton and sorghum in an agroforestry system of Shea trees (Vitellaria paradoxa Gaertn) in northern Benin. Nat Sci 5:207-213

Gwenzi W, Chaukura N, Mukome FND, Machado S, Nyamasoka B (2015) Biochar production and applications in subSaharan Africa: opportunities, constraints, risks and uncertainties. J Environ Manag 150:250-261. doi:10.1016/ j.jenvman.2014.11.027

Hardie M, Clothier B, Bound S, Oliver G, Close D (2014) Does biochar influence soil physical properties and soil water availability? Plant Soil 376:347-361. doi:10.1007/s11104013-1980-x

Hauggaard-Nielsen H, Jensen ES (2005) Facilitative root interactions in intercrops. Plant Soil 274:237-250. doi:10. 1007/s11104-004-1305-1

IITA (2007) International Institute of Tropical Agriculture. Southern Sudan, Equatoria Region, Cassava Baseline Survey, Technical Report, pp. 67. www.iita.org. Accessed 16 April 2008

Jeffery S, Bezemer TM, Cornelissen G, Kuypert TW, Lehmann J, Mommer L, Sohi SP, Van De Voordet F, Wardle DA, Van Groenigen JW (2015) The way forward in biochar research: targeting trade-offs between the potential wins. GCB Bioenergy 7:1-13. doi:10.1111/gcbb.12132

Kessler JJ (1992) The influence of karité (Vitellaria paradoxa) and néré (Parkia biglobosa) trees on sorghum production in Burkina Faso. Agrofor Syst 17:97-118

Kimetu J, Lehmann J, Ngoze S, Mugendi D, Kinyangi J, Riha S, Verchot L, Recha J, Pell A (2008) Reversibility of soil productivity decline with organic matter of differing quality along a degradation gradient. Ecosystems 11:726-739

Lehmann J, Joseph S (2009): Lehmann J, Joseph S (ed) Biochar for environmental management: science and technology, 1st edn. Earthscan, London, pp. 1-12

Lehmann J, Rondon M (2006) Biochar soil management on highly weathered soils in the humid tropics. In: Uphoff $\mathrm{N}$ (ed) Biological approaches to sustainable soil systems, 1st edn. CRC Press, Boca Raton, Florida, pp 517-530

Lentz RD, Ippolito JA (2012) Biochar and manure affect calcareous soil and corn silage nutrient concentrations and uptake. J Environ Qual 41:1033-1043 
Liang B, Lehmann J, Solomon D, Kinyangi J, Grossman J, O'Neill B, Skjemstad JO, Thies J, Luizão FJ, Petersen J, Neves EG (2006) Black carbon increases cation exchange capacity in soils. Soil Sci Soc Am J 70:1719-1730. doi:10. 2136/sssaj2005.0383

Liu X, Zhang A, Ji C, Joseph S, Bian R, Li L, Pan G, PazFerreiro J (2013) Biochar's effect on crop productivity and the dependence on experimental conditions-a metaanalysis of literature data. Plant Soil 373:583-594. doi:10. 1007/s11104-013-1806-x

Major J, Rondon M, Molina D, Riha S, Lehmann J (2010) Maize yield and nutrition during 4 years after biochar application to a Colombian savanna oxisol. Plant Soil 333:117-128. doi:10.1007/s11104-010-0327-0

Masutha TH, Muofhe ML, Dakora FD (1997) Evaluation of $\mathrm{N}_{2}$ fixation and agroforestry potential in selected tree legumes for sustainable use in South Africa. Soil Biol Biochem 29:993-998

Mohammed HM, Röhle H (2011) Studying the competition in natural stands of Acacia seyal Del. variety seyal. Forestry Ideas 17(1): 34-44

Nair PKR (1993) An introduction to agroforestry. Kluwer Academic Publishers, Dordrecht. ISBN 0-7923-2134-0

Nair PKR, Garrity D (2012) Agroforestry research and development: the way forward. In: Nair PKR, Garrity D (eds) Agroforestry-the future of global land use (Advances in Agroforestry 9). Springer, Dordrecht, pp 515-531

Nelissen V, Ruysschaert G, Müller-Stöver D, Bodé S, Cook J, Ronsse F, Shackley S, Boeckx P, Hauggaard-Nielsen H (2014) Short-term effect of feedstock and pyrolysis temperature on biochar characteristics, soil and crop response in temperate soils. Agronomy 4:52-73. doi:10.3390/ agronomy 4010052

Novak JM, Busscher WJ, Watts DW, Laird DA, Ahmedna MA, Niandou MAS (2010) Short-term $\mathrm{CO}_{2}$ mineralization after additions of biochar and switchgrass to a Typic Kandiudult. Geoderma 154:281-288

Olembo KN, M'mboyi F, Kiplagat S, Sitieney JK, Oyugi FK (2010) Sorghum Breeding in Sub-Saharan Africa: The Success Stories. African Biotechnology Stakeholders Forum (ABSF), Nairobi

Ong CK, Leakey RRBCK (1999) Why tree-crop interactions in agroforestry appear at odds with tree-grass interactions in tropical savannahs. Agrofor Syst 45:109-129

Ouyang L, Wang F, Tang J, Yu L, Zhang R (2013) Effects of biochar amendment on soil aggregates and hydraulic properties. J Soil Sci Plant Nutr 13(4):991-1002

Palm CA (1995) Contribution of agroforestry trees to nutrient requirements of intercropped plants. Agrofor Syst 30: $105-124$

Peng X, Ye LL, Wang CH, Zhou H, Sun B (2011) Temperature and duration-dependent rice straw-derived biochar: characteristics and its effects on soil properties of an Ultisol in southern China. Soil Tillage Res 112:159-166

Raddad EY, Luukkanen O (2007) The influence of different Acacia senegal agroforestry systems on soil water and crop yields in clay soils of the Blue Nile region, Sudan. Agric Water Manag 87:61-72

Raddad EY, Luukkanen O, Salih AA, Kaarakka V, Elfadl MA (2006) Productivity and nutrient cycling in young Acacia senegal farming systems on Vertisol in the Blue Nile region, Sudan. Agrofor Syst 68:193-207. doi:10.1007/ s10457-006-9009-6

Rondon MA, Lehmann L, Ramírez J, Hurtado M (2007) Biological nitrogen fixation by common beans (Phaseolus vulgaris L.) increases with bio-char additions. Biol Fertil Soils 43:699-708. doi:10.1007/s00374-006-0152-z

Saxton KE, Rawls WJ (2006) Soil water characteristic estimates by texture and organic matter for hydrologic solutions. Soil Sci Soc Am J 70:1569-1578. doi:10.2136/sssaj2005

Schenkel Y, Bertaux P, VanWijnbserghe S, Carre J (1998) An evaluation of the mound kiln carbonization technique. Biomass Bioenergy 14:505-516

Sohi SP, Krull E, Lopez-Capel E, Bol R (2010) A review of biochar and its use and function in soil. Adv Agron 105:47-82. doi:10.1016/S0065-2113(10)05002-9

Stavi I, Lal R (2013) Agroforestry and biochar to offset climate change: a review. Agron Sustain Dev 33:81-96. doi:10. 1007/s13593-012-0081-1

Steiner C, Teixeira WG, Lehmann J, Nehls T, de Macedo JLV, Blum WEH, Zech W (2007) Long term effects of manure, charcoal and mineral fertilization on crop production and fertility on a highly weathered Central Amazonian upland soil. Plant Soil 291:275-290

Suresh G, Rao JV (1999) Intercropping sorghum with nitrogen fixing trees in semiarid India. Agrofor Syst 42:181-194

Tammeorg P, Simojoki A, Mäkelä P, Stoddard F, Alakukku L, Helenius J (2014a) Biochar application to a fertile sandy clay loam in boreal conditions: effects on soil properties and yield formation of wheat, turnip rape and faba bean. Plant Soil 374:89-107 (Erratum Plant Soil 379: 389-390)

Tammeorg P, Parviainen T, Nuutinen V, Simojoki A, Vaara E, Helenius J (2014b) Effects of biochar on earthworms in arable soil: avoidance test and field trial in boreal loamy sand. Agric Ecosyst Environ 191:150-157

Tammeorg P, Simojoki A, Mäkelä P, Stoddard F, Alakukku L, Helenius J (2014c) Short-term effects of biochar on soil properties and wheat yield formation with meat bone meal and inorganic fertiliser on a boreal loamy sand. Agric Ecosyst Environ 191:108-116

UNEP (2007) United Nations Environnent programme. Sudan Post-Conflict Environmental Assessment report. Nairobi, Kenya. www.unep.org/sudan/post-conflict/PDF/UNEP_ Sudan.pdf

Van Zwieten L, Kimber S, Morris S, Chan YK, Downie A, Rust J, Joseph S, Cowie A (2010) Effect of biochar from slow pyrolysis of papermill waste on agronomic performance and soil fertility. Plant Soil 327(1-2):235-246

Van Zwieten L, Rose T, Herridge D, Kimber S, Rust J, Cowie A, Morris S (2015) Enhanced biological N2 fixation and yield of faba bean (Vicia faba L.) in an acid soil following biochar addition: dissection of causal mechanisms. Plant Soil. Open Access. doi: 10.1007/s11104-015-2427-3

Wilson TD, Brook RM, Tomlinson HF (1998) Interaction between Néré (Parkia biglobosa) and under-planted sorghum in parkland systems in Burkina Faso. Exp Agric 34(1):85-99. doi:10.1017/S0014479798001069

Woolf D, Amonette JE, Street-Perrot FA, Lehmann J, Joseph S (2010) Sustainable biochar to mitigate global climate change. Nat Commun 1(56):1-9. doi:10.1038/ncomms1053

Young A (1989) Agroforestry for soil conservation. ICRAF, CAB International Publications, Nairobi, p 27 